UDC 811.111:81

https://doi.org/10.31548/philolog2021.02.104

\title{
THE GENRE DIFFERENTIATION AND LINGUISTIC PECULIARITIES OF ENGLISH DIPLOMATIC DISCOURSE
}

\author{
M. G. GOLTSOVA, PhD in Philology, Associate Professor, \\ National University of Life and Environmental Sciences of Ukraine \\ E-mail: mariam88@ukr.net \\ https://orcid.org/ 0000-0003-2385-436X
}
A. V. KHODARCHENKO, Bachelor of Philology, Kyiv National Linguistic University
E-mail: anastasiiahodor@gmail.com
https://orcid.org/0000-0002-0975-2933

\begin{abstract}
This paper deals with English diplomatic discourse as an independent type of discourse, which is characterized by its genre typology. The goals of diplomacy and diplomatic discourse are to protect the national and state interests and to implement norms and values in the context of globalization.

For a long time, diplomatic discourse has been a part of political discourse. English diplomatic discourse has its own unique features and parameters that set it apart from other types of institutional discourse. Diplomatic discourse is a complex communicative phenomenon that covers the entire spectrum of diplomatic interactions. There are accurate and regulated standards and requirements for writing diplomatic documents, that depend on and vary according to the genre typology.

The research's relevance is found in the growing interest of contemporary linguistics in the issues of communicative interaction and the study of language in close connection with the practical actions of a person. The paper attempts to systematize knowledge about the texts used in international relations.

The fact that English diplomatic documents are widely used determines their genre diversity. Documents of diplomatic discourse are divided into 7 groups: contractual (agreement, treaty, pact), informative (resolution; government statement), instructive (verbal note; circular note), argumentative (diplomatic speech; letter of concern), regulatory (communiqué; verbal note; memorandum), authoritarian (declaration; act), courteous (letter of invitation; letter of condolence). This division of diplomatic texts is performed on the basis of Nataliya Kashchyshyn's classification of taxonomic units in English diplomatic discourse and makes it possible to consider structural, terminological and pragmatic factors in the formation of diplomatic documents. The purpose of diplomatic discourse is to protect national interests, prevent war and strengthen peace, as well as to implement foreign policy on behalf of the state.
\end{abstract}

Keywords: diplomatic discourse, diplomatic document, diplomacy, genre typology.

A diplomat is a man who always remembers a woman's birthday but never remembers her age.

Robert Frost

Introduction. The type of discourse is defined by the kind of social activity though which it is realized and the goals with which it is correlated. According to V. I. Karasyk [1], in terms of sociolinguistics, there are two groups of discourses that of personal (personality-oriented) discourse and that of institutional (status-role) discourse. Institutional discourse is based on such systemforming features as: goals, participants in communication, chronotopes, values, strategies, material, varieties and genres, precedent (culturecreating) texts and discursive formulas.

For a long time, diplomatic discourse was a part of political discourse. However, the increasing necessity of diplomacy nowadays is what made the separation of diplomatic discourse in today's globalizing world crucial.

The term 'diplomatic discourse' has been introduced into scientific circulation relatively recently. (c) M. G. Goltsova, A. V. Khodarchenko

The concept of 'diplomacy' is usually associated with the art of negotiating to prevent or resolve conflicts, seek compromises and mutually agreed-upon solutions, and expand and deepen international cooperation. In other words, diplomacy can be defined as the art and practice of conducting negotiations between representatives of groups or states and improving international relations with regard to issues of peace-making, trade, war, economics and culture. The ability to practice diplomacy is one of the defining attributes of a state, and diplomacy has been practiced since the first states were formed.

Thus, methods of using language and speech in diplomatic documents are the principal tools for non-military measures and negotiations. Therefore, the need to describe, systematize and classify diplomatic discourse is obvious. According to N. Kashchyshyn [2], diplomatic discourse is a system 
of linguistic means that reflects the communicative situations generated by the institutions of diplomacy and international communication.

Recent research and publications. Diplomatic discourse has been the subject of numerous linguistic investigations in recent years (N. Kravchenko [3], Y. Sudus [4], N. Kashchyshyn [2] etc.). Kashchyshyn explored the distinctive features of diplomatic discourse such as prescriptiveness, institutionality, rituality, international and intercultural character as well as the origins of English diplomatic terminology. In her thesis, Speech Tactics of Discrediting Strategy in American English Diplomatic Discourse, Y. Sudus focused on modern American English diplomatic discourse, related to the military conflict in eastern Ukraine [4]. Faizullaev A. and Cornut J. [5] have analysed international conflicts through defining and discussing narrative practices. The authors identify various sites where clashes between narratives materialise and specific narrative practices are performed: in traditional diplomacy, in public diplomacy and in the media.

The aim of the current paper is to study the characteristic features and genres of diplomatic discourse.

Results. Diplomatic discourse is a stable system of status-role relations within the communicative space of the social institution of diplomacy. The heart of institutional discourse is the communication of its participants: the sender of the message generates and sends an oral or written message; the addressee of the message listens or reads and decodes the message. In diplomatic discourse, the addressee is a representative of the institute of diplomacy (professional diplomats - officials of the foreign ministry) or representatives of political circles (heads of state and government) who are involved in the implementation of foreign policy as well as the protection of rights and interests abroad.

The goals of diplomacy and diplomatic discourse are the protection and support of national and state interests, the implementation of norms and values in the context of globalization, and the internationalization of the world community. Diplomacy, which occurs in an international, intercultural context, requires a connection with communication and culture. In other words, the purpose of diplomatic communication is to inform and motivate action.

The communicative and functional characteristic of diplomatic discourse is the transmission and storage of information on the one hand, and the impact on the recipient of that information on the other, which is why diplomatic discourse has a well-defined purpose and pragmatic attitude. Diplomatic discourse has subdivision of organization, as well as communicative forms and means. Therefore, it is possible to identify diplomatic communication as:

1) cognitive communication (transmission of necessary information);

2) persuasive communication (formation of value orientations and attitudes);

3) expressive communication (motivation for a required action);

4) suggestive communication (influence on motivation, attitudes, behaviour);

5) ritual communication (maintenance of conventional relations).

Diplomatic discourse is a complex communicative phenomenon that covers the entire system of diplomatic interactions. As Richard Holbrooke once said: "Diplomacy is like jazz: endless variations on a theme". It is implemented in oral and written form and regulated by the rigid framework of its characteristics. There are accurate and regulated standards and requirements for writing diplomatic documents, which depend on and vary according to genre typology.

According to Kashchyshyn [2], the existing genres of diplomatic documents are divided into major seven types: 1) contractual, 2) informative, 3) instructive, 4) argumentative, 5) regulatory, 6) authoritarian, 7) courteous (see Table 1).

Table 1. Genres of diplomatic documents

\begin{tabular}{|l|l|}
\hline \multicolumn{1}{|c|}{$\begin{array}{c}\text { Types of diplomatic } \\
\text { documents }\end{array}$} & \multicolumn{1}{c|}{ Examples } \\
\hline contractual & contract; agreement; treatise; pact; convention; cartel; exchange of notes, concordat; \\
\hline informative & $\begin{array}{l}\text { personal note, collective note, circular note; resolution, statement of the Ministry of Foreign Affairs; } \\
\text { government statement; telegram; consular exequatur; }\end{array}$ \\
\hline instructive & verbal note; circular note; \\
\hline argumentative & $\begin{array}{l}\text { diplomatic speech; private letter; personal message; note of the government; letter of concern; statement / } \\
\text { speech at the conference; }\end{array}$ \\
\hline regulatory & verbal note; communiqué; memorandum; memo; \\
\hline authoritarian & note of the government (heads of state); declaration; act; communiqué; memorandum; persona non grata; \\
\hline courteous & telegram, personal letter; official invitation; greeting card; letter of sympathy \\
\hline
\end{tabular}


This division makes it possible to consider structural, terminological and pragmatic factors in the formation of diplomatic documents. The only requirements of diplomatic documents are convincing arguments, high literacy, clarity of presentation and logical consistency.

According to ambassador Stanko Nick [6], who takes a practical approach, examining issues such as the choice of language in bilateral and multilateral meetings, the messages conveyed by language choice, difficulties posed by interpretation etc., language is not a simple tool but "often the very essence of the diplomatic vocation." S. Nick asserts that the choice of the right words is extremely important in diplomacy. A very carefully balanced, restrained, and moderate diplomatic vocabulary has been developed through the centuries. The usage of this vocabulary ensures a particular way of refined control over nuances in the meaning of words - both when agreeing with one's interlocutor as well as in rejecting his views, but trying to avoid undesired offence [6, p. 44].

A very important idea was written by ambassador Stanko Nick in his paper Use of language in diplomacy. The author emphasizes that "when a diplomat interprets his interlocutor's language and even single words used in a dialogue or correspondence, he always starts from the presumption that the choice of words and phrasing has been conscientious and deliberate. Nobody should nor indeed does assume that the words used are the result of insufficient knowledge of a language,

\section{Список використаних джерел}

1. Карасик В. И. Язык социального статуса: монография. Волгоград: ВГСПУ, 1991. 495 с.

2. Кащишин Н. Є. Диференціація таксономічних одиниць англомовного дипломатичного дискурсу. Східноєвропейський журнал психолінгвістики. Том 1, №2, 2014. 54-62 с.

3. Кравченко Н. К. Міжнародно-правовий дискурс: когнітивно-комунікативний аспект: рукоп. дис. на здобуття наук. ступеня д-ра філологічних наук: 10. 02. 15. Київ, 2007. 488 с.

4. Судус Ю. В. Мовленнєві тактики реалізації стратегії дискредитації в англомовному дипломатичному дискурсі: рук. дис.: 24.01.2018. Запоріжжя, 2018. 21 c.

5. Faizullaev A. Cornut J. Narrative practice in international politics and diplomacy: the case of the Crimean crisis. Journal of International Relations and Development. 2017. Vol. 20, № 3. P. 578-604.

6. Nick S., Kurbalija, J., Slavik H. (eds). Use of language in diplomacy. Language and Diplomacy. Mediterranean Academy of Diplomatic Studies. 2001. P. 39-47.

\section{References}

1. Karasik, V. I. (1991). Yazyik sotsial'nogo statusa: monografiya. [The language of the social inadequate translation or even less - a momentary bad mood! Knowing that the text will be scrutinised in such a way, the speaker or writer has to be accordingly careful about the formulations they use. This is more sensitive when preparing a written text since it cannot be softened or corrected once it has been sent out, while in conversation - if the reaction of the other side is negative - one can always say "Let me explain..." or "In other words..." and then declare something completely different from the original version [6, p. 44].

Conclusion. Diplomatic discourse is a stable system of status-role relations within the communicative space of the social institution of diplomacy. The fact that English diplomatic documents are widely used determines their genre diversity.

The aim of diplomatic discourse is to protect national interests, to prevent war and to strengthen peace, while implementing foreign policy on behalf of the state. Thus, the fundamental condition for diplomatic communication is the presence of inconsistency of views, interests, and opinions of the members in the interaction. The principal means and methods of diplomatic discourse are diplomatic correspondence and negotiations, the results of which are documented.

The accuracy, precision, correctness and adequate perception of an utterance depends on the knowledge of diplomatic language, the peculiarities of diplomatic vocabulary and diplomatic protocol.

status: monograph]: Volgograd: VGSPU. 495.

2. Kashchyshyn, N. Ye. (2014). Dyferentsiatsiia taksonomichnykh odynyts anhlomovnoho dyplomatychnoho dyskursu: dys [The Differentiation of Taxonomic Units in English Diplomatic Discourse]. East European Journal of Psycholinguistics. Vol. 1, Number 2. 54-62.

3. Kravchenko, N. K. (2007). Mizhnarodnopravovyi dyskurs: kohnityvno-komunikatyvnyi aspect [International law discourse: cognitive and communicative aspect]: rukop. dys. na zdobuttia nauk. stupenia d-ra filolohichnykh nauk: 10. 02. 15. Kyiv, 488.

4. Sudus, Yu. V. (2018). Movlennievi taktyky realizatsii stratehii dyskredytatsii $\mathrm{v}$ anhlomovnomu dyplomatychnomu dyskursi [Speech Tactics of Discrediting Strategy in English Diplomatic Discourse]: ruk. dys. Zaporizhzhia. 21.

5. Faizullaev, A., Cornut, J. (2017). Narrative practice in international politics and diplomacy: the case of the Crimean crisis. Journal of International Relations and Development. Vol. 20, № 3. P. 578604.

6. Nick, S., Kurbalija, J., Slavik, H. (eds) (2001). Use of language in diplomacy. Language and Diplomacy. Mediterranean Academy of Diplomatic Studies. P. 39-47. 


\title{
ЖАНРОВА ДИФЕРЕНЦІАЦІЯ ТА ЛІНГВІСТИЧНІ ОСОБЛИВОСТІ АНГЛОМОВНОГО ДИПЛОМАТИЧНОГО ДИСКУРСУ \\ М. Г. Гольцова, А. В. Ходарченко
}

\begin{abstract}
Анотація. у статmі висвітлена загальна характеристика та жанрова типологія документів дипломатичного дискурсу. Дипломатичний дискурс $є$ системою статусно-рольових відносин, що склалися в комунікативному просторі соціального інституту дипломатії та міжнародної комунікації. Цілями дипломатії $\epsilon$ захист інтересів держави та впровадження норм $і$ цінностей у контексті глобалізації світового суспільства.
\end{abstract}

Дипломатичний дискурс має певну цілеспрямованість $і$ прагматичну установку. Комунікативно-фрунціональна характеристика дипломатичного дискурсу характеризується передачею та зберіганням інформації, а також впливом на одержувача інформації. Дипломатичну комунікацію можна визначити як 1) пізнавальну комунікацію (передачу необхідної інфрормації); 2) переконуючу комунікацію (формування ціннісних орієнтацій i установок); 3) експресивну комунікацію (спонукання до необхідної дії); 4) сугестивну комунікацію (вплив для зміни мотивації, установок, поведінки); 5) ритуальну комунікацію (підтримання конвенціональних відносин).

Факт широкого застосування англомовних дипломатичних документів зумовлює їх жанрове різноманіття. Документи дипломатичного дискурсу поділяються на 7 груп: договірні (угода, трактат, агреман; пакт), інфрормативні (резолюція, заяву уряду), інструктивні (вербальна нота, циркулярна нота), аргументативні (дипломатична промова; нота уряду лист-занепокоєння), регулятивні (комюніке; пам'ятна записка), авторитарні (декларація; акт; комюніке), кортезивні (лист-запрошення; лист-співчуття). Такий поділ дає змогу враховувати структурні, термінологічні та прагматичні чинники формування дипломатичних документів. Єдиними вимогами до дипломатичних документів є надання переконливих аргументів, висока грамотність, чіткість викладу, логічна послідовність, правильне виділення головного змісту. Метою ж дипломатичного дискурсу є забезпечення захисту національних інтересів і благополуччя народу, здійснення зовнішньополітичної діяльності від імені держави.

Ключові слова: дипломатичний дискурс, дипломатичний документ, дипломатія, жанрова типологія. 